УДК: $7.034 \ldots 7$

ББК: 85.14

A43

DOI:10.18688/aa166-6-49

Alessandro Cosma

\title{
Paintings for the Knights of Malta. Mattia Preti and the Celebration of Martyrdom
}

In 1642, Mattia Preti was appointed Knight of the Order of St. John by Urban VIII, and in 1661 he settled in Malta, where he died in 1699 [22, pp. 9-10, 27-28]. Arriving on the island, Preti progressively became the official painter of the Knights of Malta, radically changing their way of understanding and using the images [1; 22, pp. 89-129]. From this point of view, the scenes of martyrdom represent a privileged field of investigation: for members of the Order these particular images were not only the result of specific devotions, but the representation of something that could be really experienced by them in their centuries-old fight against the Turks and often summarized their aspirations and hopes ${ }^{1}$.

The importance of this topic emerges very well from the series of early works created by Preti for the Knights of Malta, starting with the magnificent Martyrdom of St. Catherine of Alexandria donated by the painter to the Langue of Italy in 1659 and placed in their church in Valletta (Ill. 136) ${ }^{2}$. Preti depicts St. Catherine, the patron of Italian knights, waiting for the martyrdom with her eyes turned towards her reward in the sky: the crown and the palm. On the left, according to the Legenda Aurea, the Emperor Maxentius regrets the end of his hopes of marrying the girl he fall in love with ${ }^{3}$. One of the key elements of the painting is the relationship with the viewer, not entrusted to the saint, but to the executioner, the only figure facing outward. He is depicted at the moment when he is about to unsheathe a sword from his scabbard. It is, in fact, an execution sword with the typical flat end [5, p. 97], surely well known to the knights who looked at the painting, as well as the turban of the man in the foreground, an explicit reference to the Turkish enemy.

The necessary complement of this painting is the Mystic Marriage of St. Catherine (Ill. 137), painted by Preti some years later for the chapel of the same Langue in the Cathedral of St. John in Valletta and dedicated to the saint of Alexandria ${ }^{4}$. In this chapel, in fact, an important relic

\footnotetext{
The canvas, painted in Naples, is most likely the painting given by Mattia Preti to the Langue of Italy for his elevation to the Knighthood of Grace [15, p. 80; 22, pp. 136-137].

${ }_{2}$ The canvas, painted in Naples, is most likely the painting given by Mattia Preti to the Langue of Italy for his elevation to the Knighthood of Grace [15, p. 80; 22, pp. 136-137].

As clearly indicated by the sad face leaning on his elbow, a detail used by Preti also in the painting in San Pietro a Maiella in Naples. According to the Legenda Aurea, in fact, the emperor tried to convince Catherine to marry him [7, vol. 2, pp. 792-793]. About the life and the iconography of the saint, see [2].

The painting is not directly documented, but it is commonly associated with a document dated 19 May 1670 related to the gilding of the stone frame. See [18; 15, pp. 56-57; 22, pp. 174-175].
} 
was preserved: the arm and the hand of Catherine. It was used in solemn processions during the feast of the saint, when it was brought to the church belonging to the Langue of Italy in order to meet another relic: the finger of Catherine [19, pp. 101-102]. The two paintings, then, were intended to be an ideal setting for this liturgy showing the will of Catherine to join Christ and the martyrdom that followed this decision. It seems no coincidence that the miraculous episode of Mystic Marriage of St. Catherine in the painting of the Cathedral is regarded as a promise of martyrdom. It is clearly shown by the black cloth on which the saint is kneeling, by the palm that she holds, and by the crown that she gets just as she receives the ring from Christ.

In addition to the Langue of Italy, the other protagonist of Mattia Preti's arrival on the island was the Aragon Grand Master Martin de Redin, who commissioned the painter a new decoration for the chapel of his Langue, the one of Aragon and Navarra. It was a project that represented a personal celebration of the Grand Master glorifying his family and his hope for an honourable death in combat [6].

In 1659, De Redin commissioned Preti the portrait of St. Francis Xavier, whose family was related to the Grand Master, with intention to spread reverence of this saint and martyr around the island [6, pp. 31-34]. Shortly after he also asked Preti to paint a magnificent altarpiece of St. George (Ill. 138). In this painting, the saint on his white horse crushes the dragon with his spear, but above all, he looks at the angel who points to the flag of Aragon and Navarre. The image represents thus St. George as the patron of the Langue, but alludes also to the crusade planned by De Redin, who wanted to follow the example of Godfrey of Boullion to free the Holy Land ${ }^{5}$. In the background, in fact, the painter added a new and unusual scene from the Legenda Aurea: St. George guides the Christian army to the siege of Jerusalem, the army that, not surprisingly, carries the flags of Aragon [6, pp. 34-35] $]^{6}$.

The two lunettes of the chapel celebrate the other patron saint of the Langue, St. Lawrence through the common episode of his martyrdom and the unusual Meeting with Pope Sixtus II (Ill. 139-140). The lives of the saint, in fact, remember that while the Pope was led to death, Lawrence asked him to die together. Sixtus, however, refused and the saint could obtain the wished martyrdom only three days later 7 . In those two paintings, Preti highlights the connections between the scenes using the same rhetorical artifices already used in the paintings of St. Catherine: the angels on top, the executioners who turn to the audience, and the people with the turban.

The choice of this unusual couple of episodes, already executed in 1661, still seems to be linked to the patronage of the Grand Master De Redin [14, pp. 69-71]. His planned crusade, in fact, did not have much success: the Grand Master had to write many letters to the kings of European countries and especially to the Pope urging them repeatedly to embrace his cause [6, pp. 35-36]. The subject of Lawrence requesting for martyrdom to the Pope Sixtus seems to be a perfect metaphor of the Grand Master who persistently asked the Pope a permission to die for the freedom of the Holy Land, exactly as he wrote to Alexander VII: "mi saria parso di demeritare il titolo che porto di Gran Maestro dello Spedale di Gierusalem, e di Custode del San-

As clearly stated by his epitaph: "DVCIS BVLLIONII EXEMPLVM SECVTVS, EXPEDITIONIS hierosolymitanae/ principibvs eVropae sese Vltro Vel dVCem, Vel Comitem obtvlit” and by numerous letters [6, pp. 35-36].

Less convincing seems to be the interpretation of the scene as the battle of Puig [11], since it was not a siege About the life and the iconography of St. Lawrence, see [4]. 
to Sepolcro di Christo Signore Nostro, se in tali congiunture io non testificassi limmenso desiderio, che tengo di trovarmi ad una tanta Impresa, e quanto mi riputerei felice se in servitio di essa io sortissi il finir dei miei giorni dove non isdegnò di morire, ed esser sepolto l'Autor della Vita". If the paintings commissioned by De Redin celebrate a single man and his dream of a crusade, the works created by Mattia Preti in the Cathedral of St. John for the two successive Grand Masters from Aragon, Raphael Cotoner (1660-1663) and Nicolas Cotoner (16631679), are the part of a greater and more coherent program celebrating the strength of the Order and his vocation to martyrdom for all the Knights.

The story begins in 1661 with the decoration of the chapel of Castile, Leon and Portugal funded by a Friar of the Langue, Thomas de Hozes [15, p. 48; 22, pp. 172-173]. The altarpiece depicts the patron saint of the chapel, St. James, presented as a patron of the Langue through the "talking coats of arms": the Lion of Leon and the Castle of Castile which bears the cross emblem of Portugal. On the right, however, the traditional symbols of the saint recall his martyrdom: the angels with a crown, the palm and the book, the broken column, and in the end the axe that killed the saint, which becomes also an allusion of his victory since on the painting is the pagan idol that is beheaded and fallen.

The two lunettes portray two famous episodes from the life of the saint ${ }^{9}$. On the right, there is the so-called St. James matamoros (Ill. 141): that is the miraculous intervention of the saint in support of Ranierus I of Asturias during the battle of Clavijo (936). It is extraordinary stage machinery that pits the triumphant cavalcade of the saint against the ruin of the Turkish troops. Moreover, there is an especially significant detail: the soldier on the right holds in his arm the head of an Ottoman. It should have been, in fact, a clear signal for the knights because chronicles of the time tell us many stories of prisoners beheaded by the Turks, who even used their heads as cannonballs [27, pp. 167-168].

On the other side of the chapel Preti painted the miraculous appearance of the Virgin of Pilar asking St. James to build a church in her honour. It is clearly suggested by the project held by one of the angels and by the others in the background, who seem to pile stones for the construction (Ill. 142).

If the first episode fits well with the context of the struggle of the knights against the Moors, the peculiar choice of the Virgin of Pilar has never been highlighted. The miracle happened neither in Castile, nor in Leon, but near Zaragoza in Aragon. So why celebrate a glory of Aragon in the chapel of another Langue?

To answer, we must look to the nave of the cathedral and, specifically, to the ceiling where Mattia Preti was painting in the same years the stories of the patron of the Knights, St. John the Baptist, on behalf of Raphael Cotoner and, after his death in 1663, his brother Nicolas, who succeeded him at the head of the Order. Without presenting here a comprehensive interpretation of the whole frescoes, we will analyse only some details useful to our topic and to understand the project of the two Cotoner Grand Masters ${ }^{10}$.

\footnotetext{
8 Letter of the Grand Master to pope Alexander VII, March 19th, 1659, Archivum Ordinis Melitae, Valletta, National Library of Malta, vol. 1435, f. 39r.

$9 \quad$ About the life and the iconography of St. James, see [12].

10 I'm currently preparing a detailed analysis of the cycle of St. John, in the meantime see [17; 22, pp. 137$155 ; 28]$.
} 
In the key moment of the Baptism of Christ, for example, the appearance of God, who proclaims the divinity of his Son, is accompanied by angels bearing the instruments of Passion. The choice of Christ, in fact, implies his sacrifice, as well as that of St. John the Baptist and that of his Knights, as shown explicitly by the portraits of Adriano de La Riviera and Alessandro Sangiorgio, who were tortured and killed by the Turks during the Great Siege of 1565 [9, pp. 99-101].

However, to follow these examples, the Order needs a guide and a clear identity suggested by other items painted on the ceiling, such as the stocco (a baton of the Grand Master), a galley, and a sword significantly in the episode of St. John speaking to the soldiers. The other example is the stocco depicted together with the hat of the Grand Master and the sword around Salome with the head of St. John. The nature of the Order is therefore a fight for faith led by the Grand Masters, who are, of course, the two Cotoner brothers as confirmed by the constant presence of their coats of arms with the branch of cotton and, above all, by the painting of the counterfacade which closes and summarizes all the decoration (Ill. 143).

Here, in fact, the program of the two Cotoners becomes explicit. In the middle, there is a personification of the religion of the Order, depicted as a girl with a sword and an armour with Maltese cross crushing the Turks. On the left, Raphael Cotoner points with his stocco to a painting of the Capitana, the flagship of the order. On the other side, Nicolas provides assistance to a sick man, thus showing the other soul of the Order, devoted to hospitality and care of the ill. Behind him a battery of cannons fires from a fortress, and several brothers lie dead on the ground receiving the palm of martyrdom by angels. It is, in my opinion, a symbolic representation of one of the most important battles of the Order: the Great Siege of 1565, when the Turks almost conquered the island. It is painted in very similar terms of a lunette by Bartolomeo Garagona once in the oratory of the Cathedral ${ }^{11}$.

After all, the painting by Mattia Preti was completed in 1666 [13, pp. 16-17; 22, pp. 157158], just the year after the celebration of the centenary of the siege, a celebration carefully prepared by the Grand Master Nicolas Cotoner [19, pp. 105, 614-615] and where the deceased friars of the Order were given the same status as martyrs: "partim sagittati, partim vero pedibs appensi, ac capitibus decoriati, Martyrium compleverunt" 12 , exactly like the figures in the image.

Then, we can go back to the two lunettes of the chapel of Castile and assume that the choice of the scenes was not only the result of the need of the Knights of the Langue of Castile, but part of the pictorial program of Grand Masters Raphael and Nicolas Cotoner who were focused on the idea of fighting the Turks and celebrating their own role. The Virgin of Pilar, in fact, appeared in Aragon, the region from which the two Cotoner brothers had come. Moreover, Nicolas built a church dedicated to the same miracle in the Auberge of the Langue of Aragon in 1674, thereby demonstrating his devotion to this episode.

My hypothesis seems to be confirmed by the important document of 1661, in which the Grand Master Raphael Cotoner releases the funds left for the decoration of the chapel by Thomas de Hozes, who died during the works, and offers his own money to pay the part of the expenses: "Sig. Gran Maestro comnadò a me Vicecancelliero di far nota, come sempre, e quando la Ven.Lingua

11 The painting is now preserved in the Franciscan Convent of Rabat. See [27, p. 166; 16, p. 85]. The different interpretation of the Allegory of the Order presented in [3] will be discussed in another paper in preparation.

${ }_{12}$ As expressly stated in the ceremony for the celebration of the siege of St. Elmo on June 23: [19, p. 409]. 
di Castiglia, e Portogallo, ò qualche Religioso di essa vogli fabricare il residuo di detta Cappella nella conformità che domandorono Sua Eminenza si esibisce à fare di borsa propria la metà della spesa"13.

Title. Paintings for the Knights of Malta. Mattia Preti and the Celebration of Martyrdom.

Author. Alessandro Cosma- Ph. D., associate professor. Sapienza University of Rome, Piazzale Aldo Moro 5, 00185 Rome, Italy. alessandro.cosma@uniroma1.it

Abstract: Upon arriving on Malta in 1660, Mattia Preti progressively became the official painter of the Knights of St. John radically changing their way of understanding and using the images. From this point of view, the scenes of martyrdom represent a privileged field of investigation: for the knights, in fact, these particular images were not only the result of specific devotions, but the representation of something that often summarized their aspirations and hopes. The paper deals with:

- the works made by Preti for the Langue of Italy, offering a comparative reading of two paintings dedicated to St. Catherine, one made for the Church of the Langue and the other for their chapel in St. John's Cathedral.

- the two lunettes in the Chapel of the Langue of Aragon dedicated to the martyrdom of St. Lawrence including them in the original commission by Grand Master Martin de Redin (1657-1660) related to his failed - project of crusade.

- the role played by the two Grand Masters, Raphael (1660-1663) and Nicolas Cotoner (1663-1680), in guiding the choice of the subjects for the paintings in the Chapel of the Langue of Castille, a prelude to the great celebration of their role in the history of the Order painted by Preti in the vault of the cathedral and, above all, in the allegory of the Order painted on the counterfacade.

Keywords: Mattia Preti; Malta; martyrdom; iconography; knights of St. John; Martin de Redin; Nicolas Cotoner; Raphael Cotoner.

Название статьи. Живопись для рыцарей Мальтийского ордена. Маттиа Прети и прославление мученичества.

Сведения об авторе. Косма Алессандро - Ph. D., доцент. Римский университет Сапиенца, площадь Альдо Моро, 5, 00185 Рим, Италия. alessandro.cosma@uniroma1.it

Аннотация. Маттиа Прети, приехавший на Мальту в 1660 г., со временем стал официальным художником мальтийских рыцарей и решительно изменил их представления об искусстве и возможностях его использования. В этом отношении интересный предмет для исследования представляют сцены мученичества. Для членов ордена эти образы были не только объектом особого почитания, но нередко и воплощением их собственного духовного опыта, устремлений и надежд.

В статье рассмотрены следующие вопросы:

- произведения, созданные Прети для Ланги Италии: две картины, посвященные св. Екатерине: одна - в церкви Итальянской Ланги, другая - в капелле в соборе Св. Иоанна;

- два люнета в капелле Арагонской Ланги с изображением мученичества св. Лаврентия, которые могут быть отнесены к числу заказов великого магистра Мартина де Редина (1657-1660), связанных с его неосуществленным проектом крестового похода;

- роль двух великих магистров - Рафаэля (1660-1663) и Николаса (1663-1680) Котонеров в выборе сюжетов для росписи капеллы Кастильской Ланги, своего рода прелюдии к прославлению их деяний в композиции «История Мальтийского ордена», созданной Прети в своде собора, и особенно в изображении аллегории Порядка на его западной стене.

Ключевые слова: Маттиа Прети; Мальта; мученичество; иконография; рыцари св. Иоанна; Мартин де Редин; Николас Котонер; Рафаэль Котонер.

\section{References}

1. Aymonino A.; Cosma A. Gran Maestri committenti di Mattia Preti: devozione, celebrazione dell'Ordine e glorificazione personale. Valletta. Città, architettura e costruzione sotto il segno della fede e della guerra. Roma, Istituto Poligrafico e Zecca dello Stato Publ., 2011, pp. 219-238 (in Italian).

13 Archivum Ordinis Melitae, Valletta, National Library of Malta, Liber Conciliorum 1659-1662, cc.221v222r, December 3rd, 1661 
2. Balboni D.; Bronzini G. B.; Orlandi M. V. Caterina d'Alessandria. Bibliotheca Sanctorum. Roma, Città Nuova Publ., 1963, vol. 3, coll. 954-976 (in Italian).

3. Capriotti G. Il pericolo turco nella committenza dei cavalieri di Malta nel XVII secolo: Caravaggio e Mattia Preti. Cavalieri: dai Templari a Napoleone. Storie di crociati, soldati, cortigiani. Milano, Electa Publ., 2009, pp. 133-141 (in Italian).

4. Carletti G.; Celletti M. C. Lorenzo. Bibliotheca Sanctorum. Roma, Città Nuova Publ., 1966, vol. 8, coll. 108-129 (in Italian).

5. Cassar R. Le armi bianche nell'arte di Mattia Preti. Mattia Preti. Della Fede e Umanità 1613-2013. Catanzaro, Abramo Publ., 2014, pp. 91-97 (in Italian).

6. Cosma A. Mattia Preti e Martin de Redin: la Cappella della Lingua d'Aragona prototipo decorativo per la Chiesa Conventuale di San Giovanni Battista. Storie di restauri nella chiesa conventuale di San Giovanni Battista a La Valletta. La cappella di Santa Caterina della Lingua d'Italia e le committenze del gran maestro Gregorio Carafa. Valletta, Midsea Books Publ., 2008, pp. 27-40 (in Italian).

7. Da Varagine J. Legenda Aurea. Firenze, Libreria Editrice Fiorentina Publ., 1990. 877 p. (in Italian).

8. De Giorgio C.; Guido S. Mattia Preti. St. Catherine of Alexandria; patron Saint of the Italian Langue of the Knights of Malta. Malta, The St. John's Co-cathedral Foundation Publ., 2005. 48 p.

9. De Giorgio C. Mattia Preti: Saints and Heroes for the Knights of Malta. Valletta, Midsea books Publ., 2014. 144 p.

10. Debono J. Art and Artisans in St. John's and Other Churches in the Maltese Islands, ca. 1650-221800: Stone Carving, Marble, Bells, Clocks and Organs. Gudja (Malta), Guttenberg Press Publ., 2005. 501 p.

11. Debono S. Interpreting Mattia Preti's St. George and the Dragon. Treasures of Malta, 2006, no. 1, pp. 68-72.

12. Fernández Alonso J. Giacomo maggiore. Bibliotheca Sanctorum. Roma, Città Nuova Publ., 1965, vol. 6, coll. 363-388 (in Italian).

13. Guido S.; Mantella G. Mattia Preti e la volta della Chiesa Conventuale di San Giovanni Battista a La Valletta: documenti e testimonianze 1661-2011 per il 350 anniversario dell'inizio lavori. I beni culturali, 2011, vol. 19, no. 3, pp. 7-28 (in Italian).

14. Guido S.; Mantella G. Mattia Preti: i primi capolavori per Malta. Restauro e nuove osservazioni. I beni culturali, 2012, vol. 20, no. 4/5, pp. 59-71 (in Italian).

15. Guido S.; Mantella G. Mattia Preti 1613-2013. The Masterpieces in the Churches of Malta. Malta, Miranda Publ., 2013. 224 p.

16. Guido S.; Mantella G. “... In ogni luogo dell'Isola di Malta ha lasciate imprese... per tutt’i secoli nell’eterna Gloria”. Opere del Gran Maestro Gregorio Carafa per la Chiesa Conventuale di San Giovanni Battista. Mattia Preti e Gregorio Carafa. Due Cavalieri gerosolimitani tra Italia e Malta, atti della giornata di studio: Valletta, 12 giugno 2013. Serra San Bruno (VV), 2015, pp. 49-61 (in Italian).

17. Mancini M. Mattia Preti e la storia di san Giovanni per la co-cattedrale di Valletta Una narrazione visiva tra allegorie e gli episodi della vita. Roma, Aracne Publ., 2008. 87 p. (in Italian).

18. Mandarano N.; Muroni A. 'Il quadro grande e li quattro picoli'. I dipinti della Cappella della Lingua d'Italia da Francesco Potenzano a Mattia Preti. Storie di restauri nella chiesa conventuale di San Giovanni Battista a La Valletta. La cappella di Santa Caterina della Lingua d'Italia e le committenze del gran maestro Gregorio Carafa. Valletta, Midsea Books Publ., 2008, pp. 205-230 (in Italian).

19. Scarabelli G. Culto e devozione dei Cavalieri a Malta. Malta, University Press Publ., 2004. 795 p. (in Italian).

20. Sciberras K. Baroque Painting in Malta. Valletta, Midsea Books Publ., 2009. 450 p.

21. Sciberras K. The Brush for the Cross, the Cross for the Brush: Mattia Preti, Knight of Malta. I cavalieri di Malta e Caravaggio. La storia, gli artisti, i committenti. Roma, Logart Press Publ., 2010, pp. 123-134.

22. Sciberras K. Mattia Preti: The Triumphant Manner. Valletta, Midsea Books Publ., 2012. 480 p.

23. Sciberras K. Mattia Preti a Malta e la maniera trionfante: un'analisi del contesto. Mattia Preti: il cavalier calabrese tra Caravaggio e Luca Giordano. Cinisello Balsamo, Silvana Editoriale Publ., 2013, pp. 47-52 (in Italian).

24. Scicluna H. P. La chiesa di San Giovanni in Valetta. Roma, Casa M. Danesi Publ., 1955. 425 p. (in Italian).

25. Sgarbi V.; Sciberras K. (eds.) Mattia Preti: il cavalier calabrese tra Caravaggio e Luca Giordano. Cinisello Balsamo, Silvana Editoriale Publ., 2013. 143 p. (in Italian).

26. Spike J. T. Mattia Preti: Catalogue Raisonné of the Paintings. Catalogo ragionato dei dipinti. Firenze, Centro Di Publ., 1999. 454 p.

27. Stone D. M. The Context of Caravaggio's 'Beheading of St. John' in Malta. The Burlington Magazine, 1997, vol. 139, no. 1128, pp. 161-170.

28. Svenningsen J. Mattia Preti's Vault in Saint John's Valletta: New Light on a Complex Iconography. Artibus et historiae, 2015, vol. 36, no. 71, pp. 281-295. 


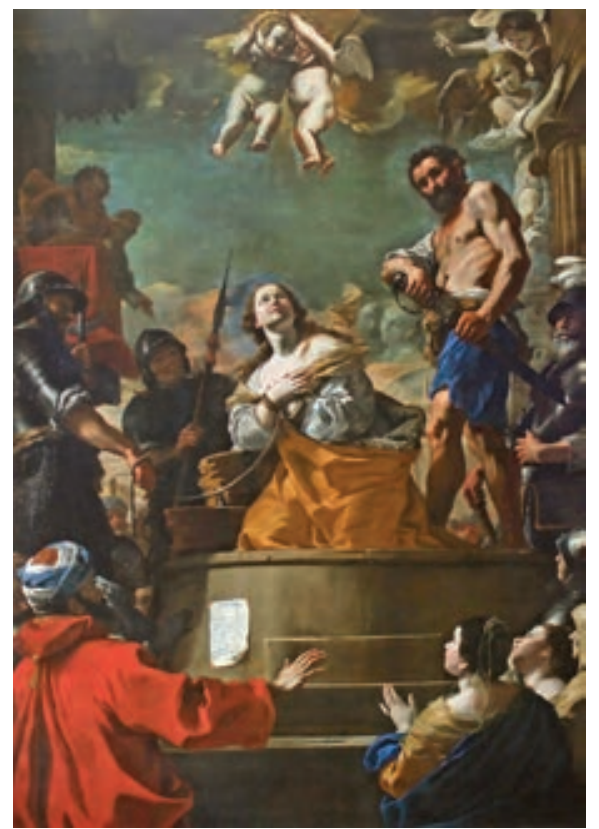

Ill. 136. Mattia Preti. Martyrdom of St. Catherine of Alexandria. Ca. 1659. Church of St. Catherine, Valletta

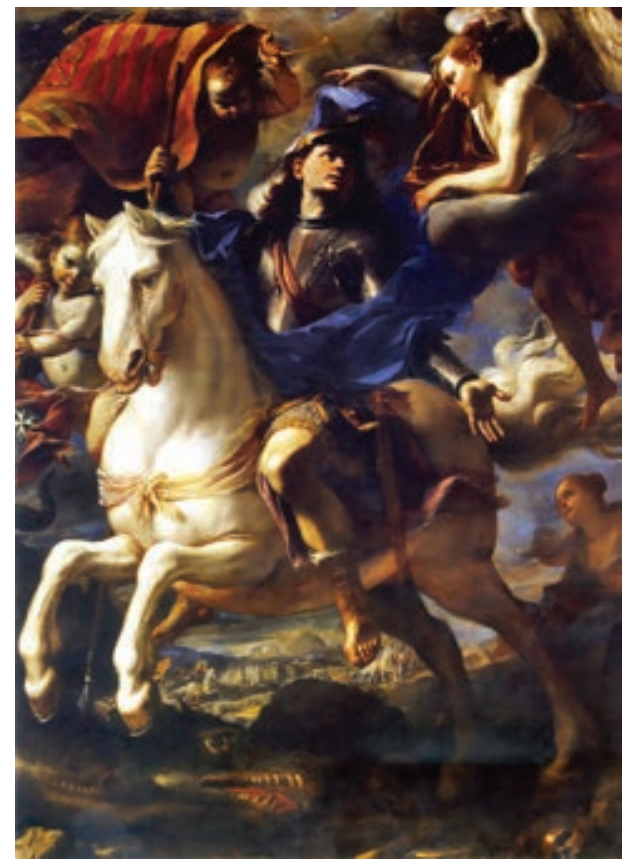

Ill. 138. Mattia Preti. St. George and the dragon. Ca. 1659. Cathedral of St. John, Valletta

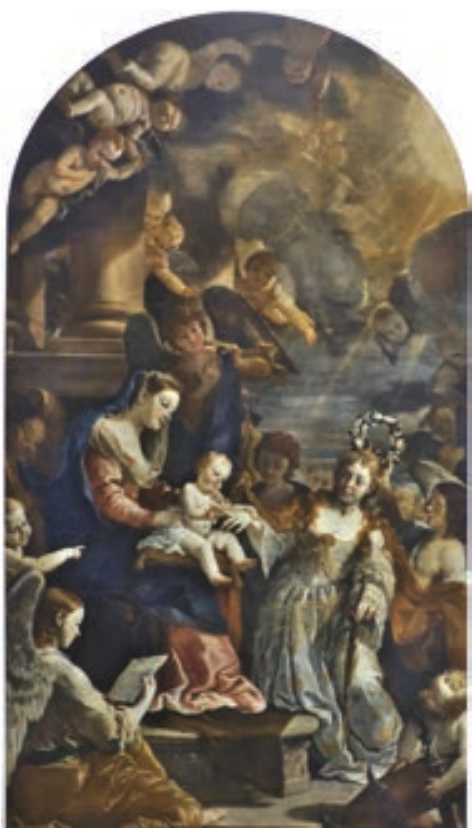

Ill. 137. Mattia Preti. Mystic Marriage of St. Catherine. Ca. 1670. Cathedral of St. John, Valletta

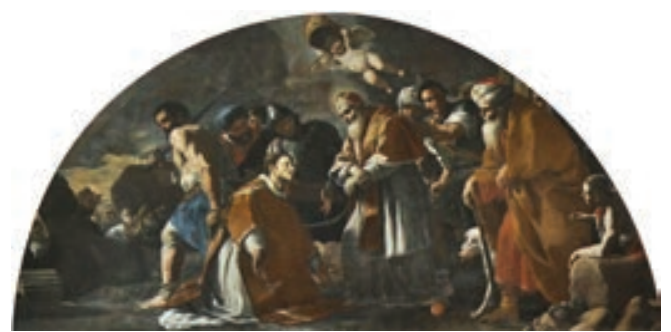

Ill. 139. Mattia Preti. St. Lawrence meeting pope Sixtus II. Ca. 1659. Cathedral of St. John, Valletta

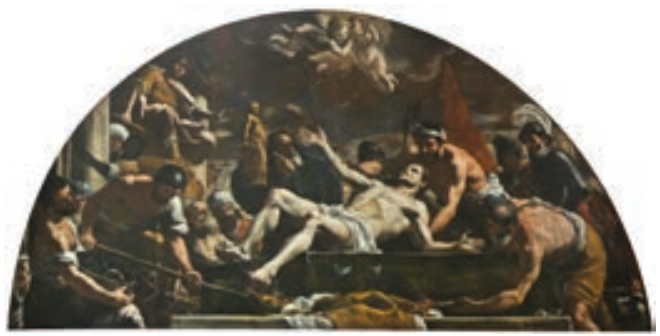

Ill. 140. Mattia Preti. Martyrdom of St. Lawrence. Ca. 1659. Cathedral of St. John, Valletta 


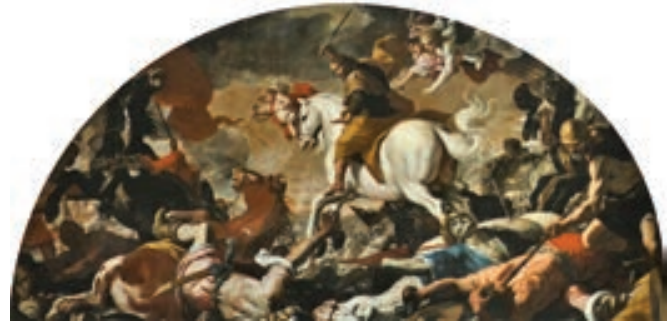

Ill. 141. Mattia Preti. St. James matamoros. Ca. 16611663. Cathedral of St. John, Valletta

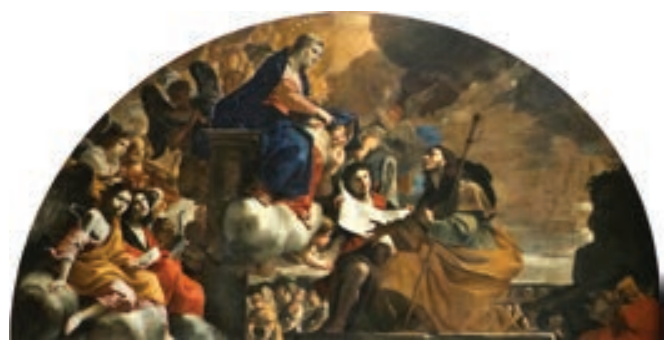

Ill. 142. Mattia Preti. St. James and the Virgin of Pilar. Ca. 1661-1663. Cathedral of St. John, Valletta

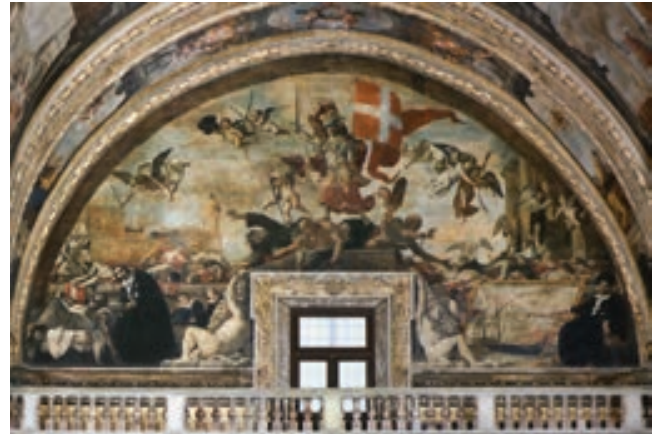

Ill. 143. Mattia Preti. Allegory of the Order. 1666. Cathedral of St. John, Valletta

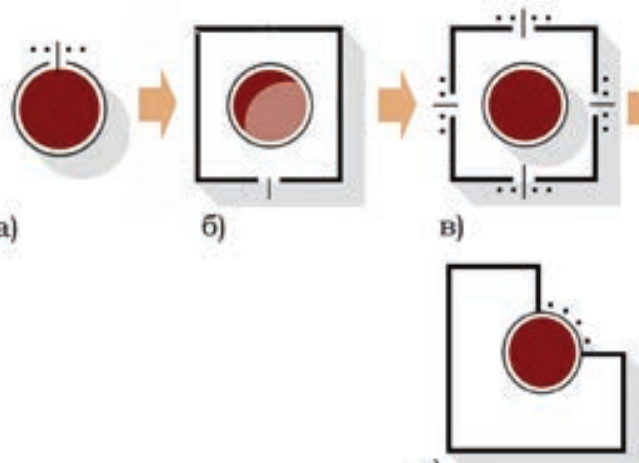

e)
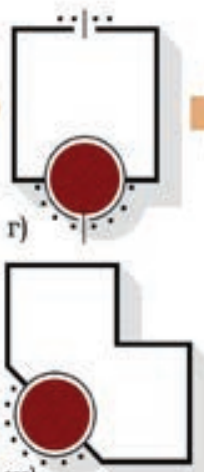

ж)
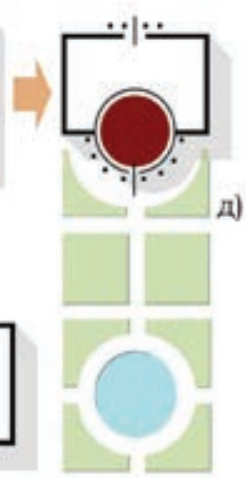

Илл. 144. Анализ генезиса ротондального модуля в объемно-пространственной композици жилого дома. Схема выполнена Ю. Г. Клименко.

а) Храм-ротонда. б) А.Мантенья. Собственный дом в Мантуе. После 1476 г. в) А. Палладио. Вилла АльмерикоКапра (Ротонда) под Виченцей (1551-1567). г) Ж. Н. Л. Дюран. Проект образцового жилого дома для городского и загородного строительства. д) П. Булле и Ж.-Б. Булле. Дворец Шамп-сюр-Марн (1699-1707). Аналогичный тип жилого здания с ротондой, обращенной в сторону сада получает широкое распространение. е) и ж) Тип «углового решения» постановки модуля ротонды в объеме партикулярного отеля для оформления городских перекрестков. В качестве сохранившихся в Париже примеров этого типа можно указать: А. Обер. Угловой жилой дом на перескрестке ул. Комартен и бульвара Мадлен (1780-1782). Р. Серж. Отель де Камондо (1911-1914). 